\title{
PEDAGOGIKA PERSONALNO-EGZYSTENCJALNA KS. JANUSZA TARNOWSKIEGO. DIALOG WYCHOWAWCZY JAKO PROPOZYCJA METODY WYCHOWANIA WE WSPÓŁCZESNEJ RODZINIE, SZKOLE, SPOŁECZEŃSTWIE
}

\author{
The Personal-Existential Pedagogy of Janusz Tarnowski. Educational \\ Dialogue as a Methodological Proposition for Education in \\ the Contemporary Family, School and Society
}

S u m m a ry: The notion of dialogue is a basic challenge of human existence, especially in interpersonal communications and interpersonal relations. It has appeared as a pedagogical category in many scientific disciplines, such as philosophy, theology, psychology and pedagogy.

On the basis of Polish pedagogy and in connection with philosophical thinking, Janusz Tarnowski (1919-2012) proposed his personal-existential approach to pedagogy, strongly rooted in the notion of dialogue. Dialogue, according to father Tarnowski, is not simply a conversation. Dialogue is a method, a process, and an attitude.

In the process of constructing an approach to Christian education focused on the person, Tarnowski utilized such categories, taken from existentialism, as authenticity, dialogue, and involvement. These categories find expression during that process of upbringing which has three goals as its aim: authenticity, dialogue and involvement. Educational dialogue, in which there is room for conversation, understanding, agreement and eventual cooperation, constitutes a method of universal utility in the process of upbringing.

Keywords: Father Janusz Tarnowski, pedagogy of dialogue, educational dialogue, upbringing

${ }^{1}$ Dr Wiesława Buczek jest wykładowcą pedagogiki ogólnej i dydaktyki w Ośrodku Doradztwa i Doskonalenia Zawodowego „Edukacja 2001” w Radomiu, nauczycielem dyplomowanym-katechetą w Publicznym Gimnazjum nr 3 im. Jana Kochanowskiego w Radomiu; e-mail: wiesiabe@interia.pl. 
Pomóc wychowankowi odnaleźć jego miejsce w życiu i powołanie osobiste w stopniowym zbliżaniu się ku dojrzałości ludzkiej i chrześcijańskiej.

ks. Janusz Tarnowski

\section{Wstęp}

Współcześnie o wychowaniu decydują różne podejścia, typologie i koncepcje wychowania. Można stwierdzić, że istnieje tyle koncepcji wychowania, ile jest koncepcji człowieka. Każda z nich wnosi własną propozycję wartości, które są bardziej lub mniej świadomie wybierane oraz realizowane przez wychowawców ${ }^{2}$. Odczuwalny kryzys wszelkich ideologii i wartości, zachwianie skuteczności oddziaływania instytucji pedagogicznych, takich jak: rodzina, szkoła i Kościół, negatywnie wpływa na wychowanie. Wydawać by się mogło, że w chrześcijańskim wychowaniu nie ma miejsca dla dyskursu edukacyjnego. Niemniej zauważamy, że istnieje pilna potrzeba wychowania w ogóle, a prawdziwe wychowanie powinno obejmować pełną formację osoby ludzkiej zarówno w perspektywie celu ostatecznego, jak i w odniesieniu do jej egzystencji. Potencjał wychowawczy tkwiący w wychowaniu chrześcijańskim daje współczesnemu wychowawcy i wychowankowi możliwość osiągnięcia dojrzałości ludzkiej i dojrzałości chrześcijańskiej $\mathrm{w}$ wymiarze indywidualnym i społecznym. Chrześcijańskie wychowanie ujmuje człowieka realnie i integralnie, czego owocem jest autentyczne wychowanie poprzez samowychowanie i permanentną formację.

$\mathrm{Na}$ gruncie wychowania chrześcijańskiego, a związana z filozoficznym myśleniem, występuje pedagogika personalno-egzystencjalna ks. Janusza Tarnowskiego, znana jako pedagogika dialogu. W swojej długoletniej pracy autor wypracował własną pedagogię opartą wyraźnie na personalizmie chrześcijańskim, wykorzystując tylko niektóre pojęcia egzystencjalizmu. Zdaniem autora ważne jest, aby relacje, jakie zachodzą między wychowawcą a wychowankiem, miały charakter symetrycznej interakcji o „ludzkim obliczu”. Celem niniejszej publikacji jest przybliżenie osoby ks. Janusza Tarnowskiego - twórcy koncepcji pedagogicznej oraz przedstawienie jego rozumienia kategorii dialogu, która w pedagogice personalno-egzystencjalnej odgrywa główną rolę. Dialog jest tu rozumiany jako metoda, proces i postawa. Dialog wychowawczy z dzieckiem-wychowankiem, w którym to jest miejsce na rozmowę, zrozumienie, porozumienie i ewentualną współpracę, stanowi propozycję, która ze względu na swe uniwersalne odniesienie może być wykorzystaną w wychowaniu przez współczesnych rodziców, nauczycieli i wychowawców.

${ }^{2}$ Marian Nowak, Teorie i koncepcje wychowania (Warszawa: Wydawnictwa Akademickie i Profesjonalne 2008), 257. 


\section{Twórca pedagogiki personalno-egzystencjalnej ks. Janusz Tarnowski}

Ksiądz, pedagog i wychowawca, niestrudzony przyjaciel dzieci, młodzieży i dorosłych. O swoich rozległych zainteresowaniach i pasjach pisał na kartach wielu książek i czasopism. Stanowią one olbrzymie bogactwo w literaturze pedagogicznej. Związane z pedagogiką dialogu w wychowaniu są w życiu księdza profesora trzy pasje, którym poświęcił swoje życie: pisarską, wychowawczą i powołanie kapłańskie, które zaczęło się zapowiadać jeszcze wcześniej niż pisarstwo i zamiłowanie pedagogiczne. Rozwój naukowy księdza profesora był związany z Katolickim Uniwersytetem Lubelskim, gdzie w 1956 roku otrzymał tytuł magistra filozofii, a już w 1962 roku obronił pracę doktorską pt. „Typologia charakteru wg Heymansa-Le Senne’a. Studium psychologiczne”, pisaną pod kierunkiem ks. prof. Józefa Pastuszki i uzyskał stopień doktora filozofii chrześcijańskiej w zakresie filozoficzno-psychologicznym. Była to rozprawa, która stanowiła i stanowi dla wychowawców cenną pomoc dydaktyczną w procesie wychowawczym. Zainspirowała powstanie chrześcijańskiej pedagogiki personalno-egzystencjalnej znanej jako pedagogika dialogu.

Ksiądz Janusz Tarnowski był również związany naukowo w latach 1966-1989 z Akademią Teologii Katolickiej. Jednocześnie prowadził zajęcia w punkcie konsultacyjnym ATK w Katowicach oraz wykładał chrześcijańską

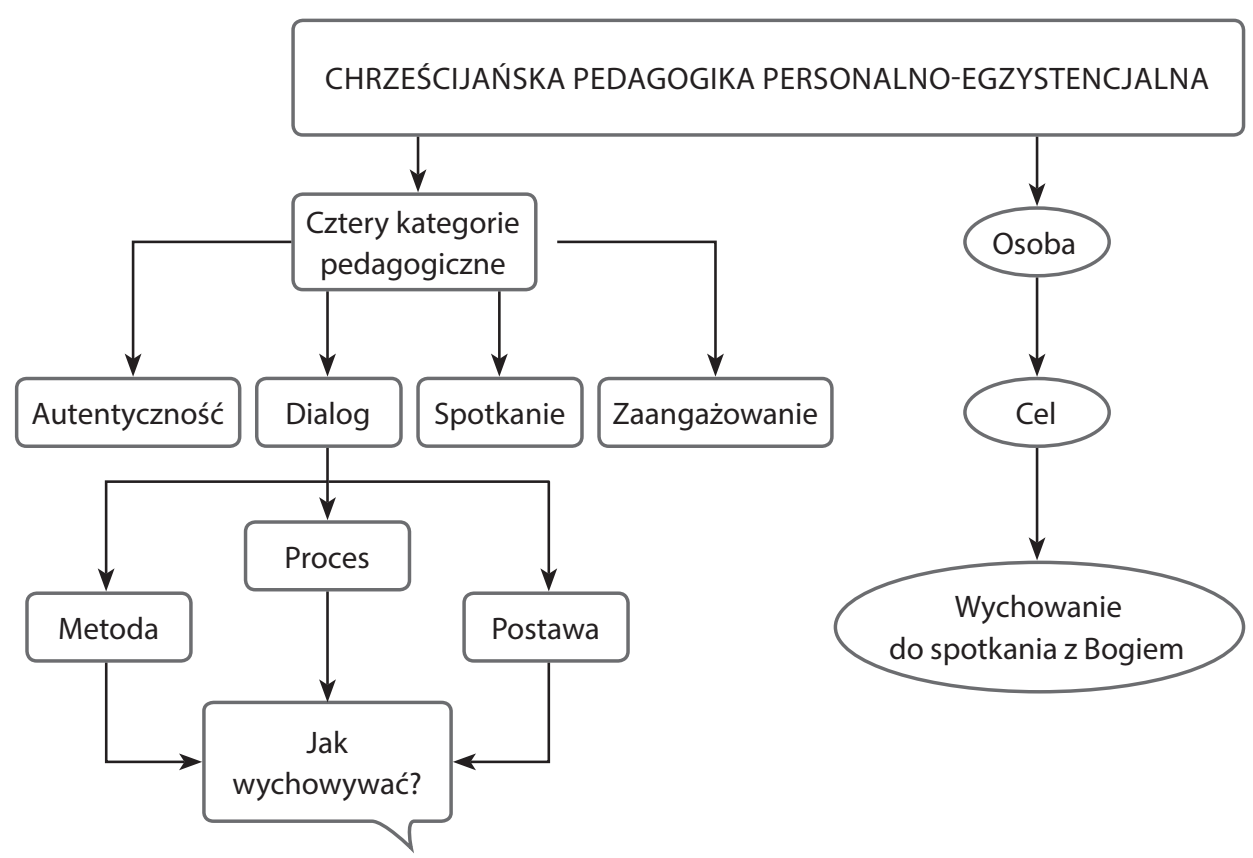

Rys. 1. Chrześcijańska pedagogika personalno-egzystencjalna

Źródło: opracowanie własne. 
pedagogikę w Wyższym Seminarium Księży Pallotynów w Ołtarzewie. Uchwałą Rady Wydziału Teologicznego ATK w dniu 9 maja 1972 roku uzyskał stopień doktora habilitowanego za rozprawę pt. Problem chrześcijańskiej pedagogiki egzystencjalnej. Na potwierdzenie habilitacji musiał czekać osiem lat, to jest do 30 czerwca 1980 roku. Wydrukowanie rozprawy habilitacyjnej nastąpiło dopiero po 10 latach (1982), ponieważ jako nielojalnemu obywatelowi odmawiano mu zgody na publikację książek. Mógł jedynie pisać artykuły, które nawiązywały do rozprawy habilitacyjnej.

Jako pedagog religijny zmierzał w swych podejmowanych wspólnotowo wysiłkach do odkrycia oraz kształtowania zasad i form współdojrzewania do dialogu z Bogiem przez Chrystusa w Kościele. W realizowaniu swych planów był niezwykle konsekwentny, a zarazem podjętą problematyką wyróżniał się spośród pedagogów religijnych i katechetów. W swej praktyce pedagogicznej ksiądz profesor postawił $\mathrm{w}$ centrum zaczerpnięte $\mathrm{z}$ egzystencjalizmu cztery kategorie pedagogiczne: autentyczność, dialog, spotkanie i zaangażowanie, a szczególną rolę nadał dialogowi. Dialog w rozumieniu autora oznacza: metodę, proces i postawę. Tak ujmowany dialog stał się początkiem szukania przez całe jego życie odpowiedzi na pytanie: jak wychowywać? Odpowiedź zawarta jest licznych publikacjach, które nie tylko pomagały wychowawcom i rodzicom dialogowo podejmować trud wychowawczy, ale także były i są inspiracją do niekończących się rozmów dialogowych $\mathrm{z}$ wychowankami i wychowawcami. Bibliografię autora można podzielić na trzy grupy:

1) źródła, w których możemy wyróżnić publikacje zwarte i serie;

2) wydawnictwa książkowe;

3) artykuły.

Całość dorobku pisarskiego autora od 1951 roku obejmuje ponad 361 pozycji. W prowadzonej działalności naukowej autor wypromował 10 profesorów, 33 doktorów, 71 magistrów. Napisał 28 recenzji do prac magisterskich lub licencjackich. Był autorem wielu komentarzy do dokumentów Urzędu Nauczycielskiego Kościoła oraz dokonał tłumaczenia na język polski między innymi Deklaracji o wychowaniu chrześcijańskim (DWCh) Soboru Watykańskiego II. Pomimo podeszłego wieku aktywność księdza profesora uwidoczniła się zarówno w dialogowych spotkaniach z wychowankami, jak i osobami, dla których dialog wychowawczy stanowił inspirację do podejmowania działań dydaktyczno-wychowawczych. Ze wszystkim osobami ksiądz profesor wspaniale odnajdował wspólny język, ponieważ unikał moralizatorstwa i suchej dydaktyki. Wnioski ks. Tarnowskiego z takich spotkań możemy odnaleźć potem w artykułach prasowych, w rozmowach na temat wychowania młodego pokolenia czy publikacjach pedagogicznych. Odejście do Pana księdza Profesora 23 października w 2012 roku nie zatrzymało dialogowych rozmów i podejmowania refleksji pedagogicznej nad dialogiem wychowawczym w pedagogice. Pytanie o wychowanie w duchu dialogu wychowawczego pozostaje otwarte i ciągle aktualne. 


\section{Pedagogika personalno-egzystencjalna ks. Janusza Tarnowskiego}

Pedagogika personalno-egzystencjalna ks. Janusza Tarnowskiego nawiązuje do chrześcijańskiego wychowania i dzięki kategoriom przejętym z egzystencjalizmu osoba pozostaje $\mathrm{w}$ niej nadal punktem oparcia w procesie wychowawczym. Wprowadzenie do wychowania przez autora kategorii pedagogicznych zaczerpniętych z egzystencjalizmu, takich jak: autentyczność, dialog, zaangażowanie, spotkanie, i połączenie ich z personalizmem, pozwala na stwierdzenie na gruncie pedagogicznym wychowania chrześcijańskiego, że zwraca się ono ku osobie ludzkiej, która otrzymała nowe istnienie - „esse Christo” - jako podstawę działania. Wprowadzone kategorie pedagogiczne mają charakter uniwersalny. Jak stwierdza ks. Tarnowski, mogą one być punktem oparcia wraz z jakąś jedną wartością szczególną lub osobą - wzorcem lub modelem, który wciela w sobie wszystkie wartości ${ }^{3}$. Według przekonania autora Jezusa Chrystusa nie da się jednak niczym ani nikim zastąpić. Swoją koncepcję ksiądz profesor nazywa „chrześcijańską pedagogiką personalno-egzystencjalną”, idąc za chrześcijańską gałęzią egzystencjalizmu i wybierając tylko to, co ma znaczenie uniwersalne dla wierzących oraz niewierzących. Rodzi to pytanie: dlaczego? Odpowiada na nie sam autor, gdy mówi:

Myślę jednak, że dzisiaj wprowadzenie przymiotnika personalna obok egzystencjalna jest pożyteczne dla koncepcji pedagogicznej. Ukazuje to bowiem powiązanie refleksji nad wychowaniem chrześcijańskim z obydwoma nurtami filozofii. Z personalizmu przejmujemy bowiem podkreślenie szczególnego znaczenia każdej osoby ludzkiej, filozofia zaś egzystencjalna ukazuje nam pojedynczego człowieka w jego konkretnych uwarunkowaniach, dążeniach, niepokojach, sukcesach i klęskach, w całym osobistym kontekście życia. Oczywiście nie może zabraknąć w pedagogice personalno-egzystencjalnej także aspektu społecznego, wspólnotowego ${ }^{4}$.

W swojej koncepcji pedagogicznej ks. Janusz Tarnowski określa relacje między osobami i między człowiekiem a Bogiem. Wychowanie w nurcie chrześcijańskiej pedagogiki personalno-egzystencjalnej jest treścią jego bogatego życia jako kapłana, pedagoga i wychowawcy. Wychodząc z osobistego doświadczenia jako teoretyka i praktyka własnej koncepcji pedagogiki dialogu, ukazuje on i proponuje wychowanie w personalizmie egzystencjalnym. Personalizm egzystencjalny przeciwstawia się autorytaryzmowi, biurokratyzacji i reformatorskiemu pozoran$\mathrm{ctwu}^{5}$, ukazuje kształcenie wychowanków i samokształcenie wychowawców.

Czym nie jest wychowanie w personalizmie? Według ks. Tarnowskiego wychowaniem $\mathrm{w}$ pedagogice dialogu nie są: tresura, administrowanie, trening,

\footnotetext{
3 Tamże, 172.

${ }^{4}$ Tamże.

5 Tamże, 66.
} 
moralizowanie i kształtowanie osobowości ${ }^{6}$. Nazywa je autor kategoriami pseudowychowania. Ponieważ tresura to nakłanianie osób pod groźbą kary lub obietnicą nagrody do pożądanych sposobów zachowania się; administrowanie to złagodzona forma tresury, ciągła nadkontrola, ocenianie, weryfikacja osoby w klimacie chłodu i oficjalności; trening - stałe ćwiczenie określonych sprawności, nieobejmujące całej osobowości wychowanka; moralizowanie - słowna perswazja lub pozasłowna sugestia zobowiązująca osobę do pożądanych zachowań; kształtowanie osobowości - zewnętrzne, przedmiotowe traktowanie całego człowieka, jako biernego obiektu czy tworzywa. W credo pedagogiki dialogu autor podaje pięć zasad, które należy zastosować $\mathrm{w}$ wychowaniu, odpierając jednocześnie zarzuty sformułowane pod adresem koncepcji chrześcijańskiej pedagogiki personalno-egzystencjalnej ${ }^{7}$. Są nimi:

1. Punkt wyjścia. W pierwszym zetknięciu się z wychowankiem lub grupą jak stwierdza autor - najistotniejsze jest wejście w jego (ich świat), z nie udawanym, ale autentycznym zainteresowaniem. Chodzi o to, aby odczuli nasz szacunek i zrozumienie i abyśmy nie zrobili niewłaściwego pierwszego kroku.

2. Wychowanek. Nie jest on kimś niższym lub mniej wartościowym od wychowawcy, ale przeciwnie, może nad nim pod wieloma względami górować. Nie jesteśmy jego sędziami. Ewentualne wady musimy dostrzegać, lecz nie wolno z nimi utożsamiać wychowanka. Trzeba zawsze w nim znaleźć obraz Boga, który go kocha i wybacza mu.

3. Relacja wychowawca-wychowanek. Zmierzać wytrwale ku przyjaźni, nie oczekując ani wdzięczności, ani przywiązania. Dać wychowankowi odczuć miłość, ale bez zasłaniania tego, który go kocha daleko bardziej: Chrystusa. Łącznikiem spajającym ma być modlitwa.

4. Proces wychowania. Wsłuchiwanie się w wychowanka. Uczenie się i wychowywanie wzajemne. Nienarzucanie i przymuszanie, lecz delikatna pomoc do budzenia zainteresowania wartościami i poszukiwania ich aż do spotkania z Bogiem w Chrystusie dzięki łasce Ducha Świętego. Nie tyle oczekiwanie natychmiastowych wyników, co raczej nadzieja na daleką przyszłość. Stała cierpliwość i atmosfera radości.

5. Cel. Pomóc wychowankowi „odnaleźć jego miejsce w życiu i powołanie osobiste w stopniowym zbliżaniu się ku dojrzałości ludzkiej i chrześcijańskiej. Jednocześnie z procesem wychowania innych dążyć do samowychowania siebie; żyć Chrystusem"».

W podstawowej dla pedagogiki dialogu relacji dialogowej wychowawcy i wychowanka niektórzy dopatrują się umniejszania roli tego pierwszego. Tak

\footnotetext{
6 Tamże, 13.

${ }^{7}$ Janusz Tarnowski, Jak wychowywać? W ogniu pytań (Ząbki: Apostolicum 2003), 175.

8 Tamże, 175.
} 
naprawdę wychowawca i wychowanek odnajdują się jednak na tym poziomie człowieczeństwa, które jest dla nich wspólne, lecz z różną odpowiedzialnością. Dialog nie musi polegać na wymianie słów. Może przyjąć formy: dialogu rzeczowego opartego na Prawdzie, dialogu personalnego opartego na Wolności i Dobru, dialogu egzystencjalnego bazującego na Miłości.

Zwracając uwagę na istotne elementy pedagogiki dialogu, możemy stwierdzić, że jest ona pedagogiką, która w dzisiejszych czasach „woła o Mistrza”. Jak mówi Martin Buber, wychowawca dzisiejszy musi mimo wszystko działać tak, „jak gdyby nie działał"'. Jego prawdziwe działanie to:

owo podniesienie palca, pytające spojrzenie. Przez niego wybór działającego świata dosięga ucznia. Wychowawca mija się z odbiorcą, przedstawiając mu ten wybór gestem wtrącania się. [...] Wtrącanie się dzieli duszę będącą przedmiotem jego zabiegów na część posłuszną i część, która się buntuje. Tymczasem siłę integrującą posiada ukryty wpływ rodzący się z pełnego wychowawcy ${ }^{10}$.

Powyższe słowa wyrażają nadzieję i tęsknotę za Mistrzem, który będzie pełnym wychowawcą i wprowadzi wychowanków w „raj czystej spontaniczności”11. $\mathrm{W}$ pedagogice dialogu mistrz nastawiony jest na głębokie złączenie z uczniem. On korzysta duchowo od ucznia, a uczeń od niego przy spełnieniu wielu uwarunkowań, między innymi przyjęciu dialogu jako elementu wychowania chrześcijańskiego. Inspiracją do zajęcia się problemem dialogu w wychowaniu i przybliżenia go współczesnym pedagogom było - jak mówi ks. J. Tarnowski - dostrzeżenie, że wychowanie religijne niejednokrotnie nie dotyka głębi osoby dziecka i młodego człowieka. Jego Autorowi brakowało ważnego momentu, jakim jest osobiste, dogłębne spotkanie z Chrystusem, które dokonałoby w wychowanku wewnętrznej przemiany. Jak stwierdza - takiego spotkania nie można wyreżyserować ${ }^{12}$, ponieważ jest ono darem Bożym. Do takiego spotkania można jednak przygotować. Ma temu służyć dialog, który nie naruszałby wolności wychowanka, a jednocześnie musiałby spełnić określone wymagania. Musiałby on być zgodny z własnym „ja” zarówno wychowawcy, jak i wychowanka, gdyż to autentyczność ma przygotować do takiego spotkania z Chrystusem, za którym powinno pójść całkowite życiowe zaangażowanie. Powinno ono występować po obu stronach osób zaangażowanych w proces wychowania.

Ks. J. Tarnowski odpowiadał też na trudne pytania związane ze współczesną szkołą. Stwierdził, że nauczyciel powinien zdążać ku mistrzostwu, czyli stawać

9 Janusz Tarnowski, „Podzwonne dla pedagogiki egzystencjalistów?”, w: Idee pedagogiki filozoficznej, red. Sławomir Sztobryn, Bogusław Śliwerski (Łódź: Wydawnictwo Uniwersytetu Łódzkiego 2003), 84.

10 Tamże.

${ }^{11}$ Martin Buber, „Wychowanie”, tłum. M.Ś. Znak 16 (1968): 448-449; zob. też: J. Tarnowski, „Kto kogo wychowuje?”, Znak 32 (1980): 1153-1164.

12 Tarnowski, „Kto kogo”, 1153-1164. 
się dla uczniów mistrzem, gdyż wychowanie nie jest aktem jednostronnym. Zachęcał nauczycieli i wychowawców odpowiedzialnych za młodego człowieka, aby wspomagali uczniów w ich rozwoju, by czasami próbowali „wejść” w tego trudnego człowieka i zrozumieli go, by poznawali jego środowisko i sytuacje życiowe ${ }^{13}$. Metoda dialogu wymaga odpowiedniego nastawienia nauczyciela, jego odejścia od dominującej pozycji w procesie edukacyjnym na rzecz pozycji partnerskiej. Wskazane jest, aby dzieci także potrafiły prowadzić dialog z rodzicami, z innymi dziećmi i z nauczycielami. Powinny one umieć stawiać pytania, słuchać odpowiedzi i rozwijać w sobie kulturę prowadzenia rozmowy.

W chwili gdy trwa dialog na temat dialogu, nie jest on należycie doceniany zarówno w nauczaniu, jak i w wychowaniu. Często bywa deformowany i sprowadzany do monologu, w którym rozmówcy siebie nawzajem ignorują. Należy zatem poszukiwać i odkrywać prawdę o człowieku, promować jego godność jako osoby i pomagać mu w rozwoju człowieczeństwa, dziś zagrożonego przez różne teorie postmodernistyczne, laicyzację życia, relatywizm moralny czy zanegowanie wszelkich wartości. Dialog wychowawczy rozumiany przez ks. Janusza Tarnowskiego jako metoda, proces i postawa ubogaca inne metody pedagogiczne, o ile te skupiają się na wychowanku, bez eksponowania jego indywidualizmu, który jest przejawem apersonalizmu, gdzie zanika dążność do dobra wspólnego i jest zagrożeniem dla życia osobowego. Dialog - jak mówi o nim Joanna Rutkowiak - jest stworzeniem szans narodzin odmiennego punktu widzenia, poszerzania bądź przebudowywania siebie, możliwego dzięki inności innych ${ }^{14}$. Każdy, kto jest zainteresowany tym, jak rozmawiać i dochodzić do porozumienia $\mathrm{z}$ innymi, mając odmienne zdanie - nie atakować, nie krytykować i nie przymuszać rozmówcy do zmiany poglądów - odnajdzie w koncepcji ks. Janusza Tarnowskiego sens i wartość. Prowadzić to może do kultury wychowania i nabywania umiejętności prowadzenia dialogu ze względu na potrzebę społeczną, ponieważ ludzka egzystencja opiera się na relacjach, które są, jak stwierdza Marian Śnieżyński, warunkiem rozwoju człowieka jako Osoby w procesie socjalizacji ${ }^{15}$. To z kolei nakłada obowiązek na osoby odpowiedzialne za wychowanie, aby efektywnie starały się wprowadzać dialog w praktykę pedagogiczną i wychowanie, gdyż doprowadzić to może do odrodzenia się zerwanych więzi między wychowankiem a wychowawcą w różnych obszarach życia rodziny, szkoły, uczelni, Kościoła czy państwa.

13 Tamże, 1164.

${ }^{14}$ Janina Rutkowiak, „O dialogu edukacyjnym. Rusztowania kategorialne”, w: Pytanie, dialog, wychowanie, red. J. Rutkowiak (Warszawa: Wydawnictwo Naukowe PWN 1992), 42.

${ }^{15}$ Marian Śnieżyński, Sztuka dialogu, teoretyczne założenia a szkolna i akademicka rzeczywistość (Kraków: Wydawnictwo Naukowe Akademii Pedagogicznej 2008), 5. 


\section{Proces edukacyjno-wychowawczy w wychowaniu do dialogu}

Jak zatem przebiega proces edukacyjny w wychowaniu chrześcijańskim do dialogu? Zgodnie z koncepcją autora metody dialogu ks. Janusza Tarnowskiego proces edukacyjny jest trójfazowy: wychowawca wpływa na wychowanka, wychowanek wpływa na wychowawcę oraz wychowują się wzajemnie. Można to przedstawić graficznie. Kolejne litery oznaczają: A - autentyczność, D - dialog, S - spotkanie, $\mathrm{Z}$ - zaangażowanie. W uproszczeniu proces wychowania można ująć następująco: AD SZ. Oznacza to, że dialog uwarunkowany autentycznością (AD) prowadzi do spotkania z Bogiem i ludźmi (S), czego wynikiem jest zaangażowanie (Z).

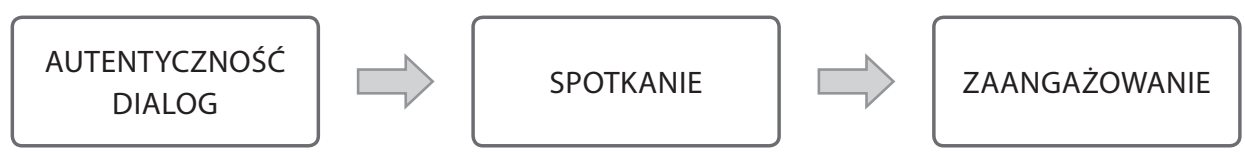

Rys. 2. Proces edukacyjny w wychowaniu do dialogu

Źródło: opracowanie własne.

Autentyczny dialog pomaga zatem $\mathrm{w}$ egzystencjalnym spotkaniu z Bogiem i ludźmi. Autentyczność egzystencjalna, o której mówi ks. Tarnowski w swej koncepcji, to autentyczność nieskażona infantylizmem i subiektywizmem. Składają się na nią trzy czynniki: GW - głębia wewnętrzna; IT - intensywny trening; $\mathbf{Z} K$ życiowa konsekwencja ${ }^{16}$. Głębia wewnętrzna ma swoje źródło w wewnętrznym „ja” osoby, w którym znajduje się obraz samego Boga. Rozwija się ona w człowieku, kiedy ten uwolni się od wpływających na niego od zewnątrz i zalewających go wciąż informacji i doznań oraz zacznie szukać swojego głębokiego „ja”, pozostanie wierny sobie, wyciszy się, a swoje serce otworzy na działanie łaski Bożej. Szukanie głębokiego „ja”, które stanowi centrum życia fizycznego, psychicznego i duchowego, nie odbywa się jednak tylko pod wpływem naszej stanowczej decyzji. To podróż do swego wnętrza - jak mówi autor - która trwa przez całe życie człowieka, a powinna być wzmacniana intensywnym, modlitewnym treningiem $^{17}$. Należy zatem stwierdzić, że proces wychowawczy w pedagogice personalno-egzystencjalnej ks. Tarnowskiego jest rzeczywistością, w której człowiek znajduje się $\mathrm{w}$ interakcji z człowiekiem, osoba wobec osoby. Ponieważ każdy człowiek daną rzecz czy rzeczywistość widzi inaczej, tym bardziej we wzajemnym

${ }^{16}$ Janusz Tarnowski, Jak wychowywać? (Warszawa: Wydawnictwa Akademii Teologii Katolickiej 1993), 79-80.

17 Tenże, „Twórcze perspektywy dialogu wychowawczego”, Chrześcijanin w Świecie 5 (1977) 53: 104-110. 
komunikowaniu się dialog jest szczególną drogą przybliżania swoich punktów widzenia i wypracowywania wspólnego ich rozumienia.

Wychowanie $\mathrm{w}$ duchu dialogu ma na celu pomoc w rozwoju człowieczeństwa wychowanka. Jednakże współczesny nauczyciel nie zawsze jest nauczycielem dialogu, lecz może nim być. Skłania go do tego wzięcie pod uwagę przy podejmowaniu działań wychowawczych złożoności czynników, które tworzą sytuacje wychowawcze. To wymaga od wychowawcy uwzględnienia, że wychowanek, jego „ja”, stanowi centrum oddziaływań wychowawczych. Wychowanek jako osoba ma swoją wartość, co sprawia, że nie może on być traktowany jako przedmiot do celu. Wychowanie ma być wsparciem i pomocą w kształtowaniu „bycia sobą” wychowanka. Powinien być on - jak stwierdza Marian Nowak - „uzdalniany do większej niezależności, do zdolności do decydowania o sobie, a także do zmieniania zastanych warunków społecznych i kulturalnych"18. Wychowanie pojmowane jako relacja między wychowawcą a wychowankiem ukazuje nam ich wzajemny wpływ na siebie, gdyż są zwróceni ku sobie i nawzajem od siebie zależą. Dialog wychowawczy jest zatem rozmową, ale nie jednorazową. Ma ona na celu współdziałanie w poszukiwaniu prawdy. W odróżnieniu od monologu zakłada uznanie godności i wolności każdego człowieka oraz prawo do wyrażania własnych poglądów. Do poznania tej prawdy zobowiązane są obie strony - wychowawca i wychowanek, rodzic i dziecko (zwłaszcza nastolatek), nauczyciel i uczeń.

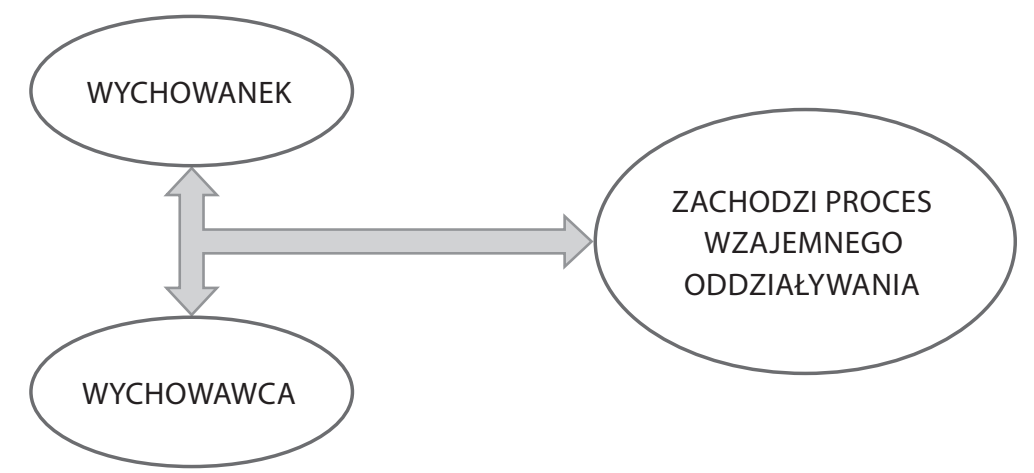

Rys. 3. Relacje w dialogu wychowawczym w pedagogice personalno-egzystencjalnej Źródło: opracowanie własne.

${ }^{18}$ Marian Nowak, Podstawy pedagogiki otwartej (Lublin: Wydawnictwo KUL 2000), 443-445. 


\section{Implikacje dialogowe do nauczania i wychowania}

Wychowanie do dialogu zaczyna się w rodzinie. Ona jest kolebką dialogu. Prawidłowy dialog w relacjach rodzic-dziecko umożliwia wzajemne poznanie, słuchanie siebie nawzajem oraz współdziałanie. Nauczenie poprawnego dialogu dziecka umożliwia mu w przyszłości zrozumienie i przezwyciężenie lęku przed szkołą, ułatwia nawiązanie kontaktów emocjonalnych z rówieśnikami i nauczycielami. Pobudza go także do refleksji nad własnym postępowaniem. Wymaga to jednak pokonania wielu przeszkód, aby go rozpocząć, i dużo cierpliwości, aby dialog był kontynuowany.

Poprawny dialog jest niezbędny w relacjach uczeń-nauczyciel, dziecko-rodzic czy dziecko-wychowawca. Podmioty podejmujące się funkcji wychowawczej nie mogą się ograniczać w działaniach wychowawczych tylko do tresury i wymagania odpowiedniego zachowania i przekazywania wiedzy. Nauczanie i wychowanie to proces trwający całe życie i oparty jest na wysiłku obu stron (wychowanka i wychowawcy), zmierzający do wieloaspektowego widzenia świata, tworzony ze znajomością wielu dróg poznania. Osoba dialogu (rodzic czy nauczyciel wykazujący postawę dialogową) powinna współtworzyć dialog wychowawczy. Miałby on na celu kształtowanie umiejętności wychowanka w budowaniu właściwych relacji w środowisku rówieśniczym i wyrażaniu własnej tożsamości. Jak stwierdza autor koncepcji pedagogiki dialogu ks. Janusz Tarnowski:

wychowanie do dialogu polega chyba na tym, żeby dzieci były od razu partnerami. Jak podkreślał Korczak - nie ma dzieci, są ludzie. [...] Dziecko traktowane z szacunkiem, które doświadczyło uznania, zobaczyło, że jego zdanie się liczy, będzie szanowało też innych. Ważne jest po prostu, żeby być w dialogu od początku z dzieckiem. W dialogu, w którym zarówno rodzice, jak i dziecko wyrażają swoje zdanie. A jednocześnie nie wolno zapominać - rodzice są odpowiedzialni za dziecko i powinni nim kierować. Cała sztuka w tym, żeby potrafić taką dialektykę wychowania wcielić w życie ${ }^{19}$.

W bezpośrednich rozmowach $\mathrm{z}$ wychowankami spotykamy jednak częściej dyskusję niż dialog. W dialogu istotne jest, aby:

- zostały przedstawione przez wychowawcę zasady współpracy;

- nauczenie dzieci mówienia bez przerywania sobie nawzajem i z poszanowaniem odmienności zdania kolegi czy koleżanki;

- wszyscy mieli szansę wypowiedzenia się na dany temat;

- uczniowie umieli słuchać siebie nawzajem.

Wypracowanie takich postaw może prowadzić do pozbawienia ucznia lęku przed wypowiadaniem się i rozmową. Wychowawca powinien zrobić wszystko, aby wprowadzać atmosferę życzliwości i otwartości we wzajemnych kontaktach. Umożliwi to wypracowanie płaszczyzny porozumienia i podjęcia ewentualnej

19 Tarnowski, Jak wychowywać? W ogniu pytań, 174-175. 
współpracy. Praktyka tak rozumianego dialogu wychowawczego przez wychowawcę prowadzi z jednej strony do budowania autentycznego autorytetu, a z drugiej - do umożliwienia wychowankowi wzrostu w jego własnym człowieczeństwie, gdyż uczy się on być sobą, podejmować samodzielnie i odpowiedzialnie decyzje, nie jest przedmiotem w wychowaniu, stara się żyć aktywnie w rodzinie i społeczeństwie. Dialog wychowawczy obok przeżywanych trudności, które mu towarzyszą, jest możliwy do zastosowania również w szkole. Wielu nauczycieli podejmuje się trudu nauczania metodą dialogu. Wymaga to od nich odpowiedniej formy lekcji, która powinna wyrabiać w uczniach zdolność samodzielnego rozwoju, kształtując w nich postawę otwartą na dialog nacechowany szacunkiem dla innych, by wspólnie poszukiwać i odkrywać uniwersalne wartości, konieczne $\mathrm{w}$ wychowaniu.

\section{Zadanie wychowawcze realizowane w rezultacie dialogu przez nauczycieli w praktyce pedagogiczno-wychowawczej}

Pytanie o wychowanie: „Jak wychowywać?”, które postawił autor koncepcji pedagogiki dialogu ks. Janusz Tarnowski ponad 60 lat temu, nadal jest obecne na ustach rodziców, nauczycieli, wychowawców. Dynamiczne zmiany, które zachodzą w rodzinie, społeczeństwie, dają możliwość podjęcia się trudu wejścia w dialog wychowawczy z wychowankiem. Dobrą sposobność ku temu tworzy rzeczywistość szkolna. Edukacja stwarza warunki do rozwoju osoby, w którym wychowanie będzie połączone ze wskazywaniem na niezbędne uniwersalne wartości. Od wielu lat obecność wartości w wychowaniu łączy się jednocześnie z pokazaniem możliwości ich realizacji. Potrzeba zauważenia dziecka jako osoby, pomocy mu w jego rozwoju i współuczestniczenia wychowawców w jego życiu, daje dialogowi wychowawczemu możliwość praktycznej jego realizacji. W dialogu wychowawczym bowiem łączenie wychowania ku wartościom $\mathrm{z}$ rozwojem osoby, pomoc $\mathrm{w}$ urzeczywistnianiu człowieczeństwa wychowanka to zadania stojące przed rodzicami oraz wychowawcami. Dialog wychowawczy umożliwia podejmowanie różnego rodzaju funkcji i zadań, jest szansą na otwarcie się nauczyciela na ucznia we wzajemnym komunikowaniu się, szczególną drogą przybliżania swoich punktów widzenia i wypracowywania wspólnego ich rozumienia i dążenia do współpracy. Praktyka tak rozumianego dialogu wychowawczego realizowanego przez nauczyciela $\mathrm{z}$ jednej strony prowadzi do budowania autentycznego autorytetu, a z drugiej - umożliwia wychowankowi wzrost w jego własnym człowieczeństwie.

Pomocą w wychowaniu chrześcijańskim są ukierunkowanie działań na wartości i autentyczność postaw rodziców. Ma to wpływ na rozwój duchowy dziecka, w którym realizuje się pomoc dziecku w nawiązaniu relacji z Bogiem. Nabyte 
umiejętności dziecka w modlitwie i prawidłowym obrazie Boga są wyrazem troski rodziców o wychowanie religijne swoich dzieci. Konieczne tu jednak okazuje się - jak stwierdza Nowak - uwzględnienie poszczególnych etapów rozwoju dziecka, jego sytuacji materialnej, psychicznej oraz religijnej ${ }^{20}$. Nowak wymienia też potrzebę podjęcia wysiłków, aby doprowadzić ideały, cele i wartości religijne do spotkania $\mathrm{z}$ wartościami życiowymi, tak aby dziecko mogło stawiać pytania odnoszące się do życia w kontekście wiary w Boga ${ }^{21}$. Takie działania ze strony rodziców powinny umożliwić otwarcie się dziecka na rzeczywistość nadprzyrodzoną. Ważne jest też, jak podkreśla Nowak, by i rodzic, i wychowawca właściwie zrozumieli swoje funkcje i uwzględnili je w procesie wychowania ${ }^{22}$.

Rodzina jako podstawa istnienia człowieka jest miejscem, gdzie dokonuje się przekaz wartości i wychowanie ku wartościom, gdzie mogą się odbywać rozmowy o wierze. Proces ten zależy od właściwego rozumienia małżeństwa i rodziny. Postawa rodziców i ich autentyczność mają znaczącą rolę wychowawczą. Przebieg procesu wychowawczego, a więc socjalizacja osoby dziecka, zależy od stopnia przygotowania rodziców do życia małżeńskiego i rodzinnego, stosowanych metod wychowawczych i własnych postaw, które dziecko zastaje i przyjmuje określone wzorce zachowań, poglądy i system wartości. Wpływ najbliższego środowiska jest tu znaczący, ponieważ $\mathrm{w}$ nim następuje formowanie systemu wartości, który powinien być konstruowany na podstawie uniwersalnych wartości. Jak stwierdza wielu pedagogów zajmujących się problematyką rodzinną, dzięki współpracy środowiska rodzinnego ze środowiskiem szkolnym można spójnie dążyć do wychowania ku wartościom. Dziecko powinno wzrastać osobowo i rozwijać swoje człowieczeństwo, a środowiska te powinny wskazywać na wartości prawdziwe i pomagać dziecku je urzeczywistniać w swojej codzienności. Dialog wychowawczy z dzieckiem-wychowankiem dający szansę na rozmowę, zrozumienie, porozumienie i ewentualną współpracę jest propozycją, która ze względu na swe uniwersalne odniesienie może być wykorzystana $\mathrm{w}$ wychowaniu chrześcijańskim. Trafne wydaje się stwierdzenie, że „wychowanie jest osobowym spotkaniem i dialogiem wychowawcy-mistrza i ucznia, który wspomaga wychowanka we wprowadzaniu w świat wartości, prowadząc go tym samym do pełni rozwoju osobowego, do głębi człowieczeństwa" ${ }^{23}$. Dialog jest tu wpisany w godność osobową wychowawcy i wychowanka, rodzica i dziecka, gdzie na płaszczyźnie rozmowy i porozumienia obie strony stają się równorzędnymi partnerami dialogu wychowawczego. Janusz Tarnowski stwierdza, że „rodzice, wychowawcy, ukazując wartości swoją postawą, przez własne świadectwo wartości, wychowują

\footnotetext{
${ }^{20}$ Nowak, Podstawy pedagogiki, 467.

${ }_{21}$ Tamże, 469.

22 Tamże, 382.

${ }^{23}$ Krystyna Chałas, Wychowanie ku wartościom. Elementy teorii i praktyki, t. 1 (Lublin-Kielce: Wydawnictwo Jedność 2003), 65.
} 
wartościami, którymi żyją, a nie tylko proponują"24. Tym samym rodzice i wychowawcy dzięki dialogowi, będąc na wspólnej płaszczyźnie z dzieckiem, mogą się również od niego wiele nauczyć. Dzięki dialogowym rozmowom możliwe jest podjęcie współpracy z podstawowymi środowiskami wychowawczymi, którymi są: rodzina, szkoła i Kościół. Obecnie wychowanie chrześcijańskie na całym świecie w wyniku realizacji uchwał II Soboru Watykańskiego uwzględnia problemy współczesności, jej cywilizacji technicznej i kultury masowej.

U progu XXI wieku jesteśmy świadkami często radykalnych zmian w rodzinie, edukacji i wychowaniu. Pedagogika dialogu staje przed szerszą możliwością jej zastosowania. Współczesna szkoła podejmuje nowe wyzwania, aby sprostać oczekiwaniom społecznym i zainteresowaniom uczniów. Placówki oświatowe wprowadzają niekonwencjonalne formy i metody pracy, pozwalające dzieciom na swobodę pracy i realizowanie programu kształcenia, przy jednoczesnym zapewnieniu klimatu bezpieczeństwa, poczucia godności, możliwości wszechstronnego rozwoju wszystkich dyspozycji poznawczych, w tym zdolności twórczego myślenia. Przykładem pozytywnym takiego działania jest powstanie w $1995 \mathrm{roku}$ „ALA” Autorskich Liceów Artystycznych we Wrocławiu i w Częstochowie. „Autorskie Licea Artystyczne i Akademickie to Liceum Ogólnokształcące i Liceum Sztuk Plastycznych tworzące zespół szkół, stanowiąc w nim jeden mocno zintegrowany organizm. Szkoły »ALA« zostały powołane z myślą o uczniach pragnących intensywnie rozwijać swoje uzdolnienia artystyczne oraz zainteresowanych dziejami kultury i jej współczesnym obrazem. W »ALA « proponowany jest nowatorski system dydaktyczno-wychowawczy, który pomaga rozwijać osobiste predyspozycje i pozwala na zaspokojenie własnych potrzeb uczenia się. Cała społeczność szkoły współpracuje $\mathrm{w}$ atmosferze wzajemnego szacunku i zaufania, wspólnego poszukiwania prawdy i wartości, w relacjach budowanych na zasadach dialogu personalnego"25. Jubileusz 10-lecia powstania szkół w 2005 roku odbył się z udziałem ks. Janusza Tarnowskiego, który dla społeczności szkolnej pozostaje mistrzem i wzorem $\mathrm{w}$ relacjach $\mathrm{z}$ młodymi ludźmi. Tutor jest tutaj zatem - jak mówił ks. prof. Janusz Tarnowski - pedagogiem prowadzącym swojego wychowanka do „mądrości”. Wdrożenie tutoringu w szkole wymaga otwartości i zgody na zmianę systemu relacji oraz sposobu pojmowania nauczycielskiego autorytetu ${ }^{26}$. Dlaczego dialog wychowawczy czy tutoring mogą coś zmienić? Ponieważ propozycja obu metod jest jedną $\mathrm{z}$ wielu możliwych dróg do zagwarantowania wolności indywidualnego rozwoju w codziennych kontaktach między wychowawcami a ich wychowankami.

${ }^{24}$ Janusz Tarnowski, Jak wychowywać? Chronić tylko...? Umacniać! W ogniu pytań (Ząbki: Apostolicum 2003), 207.

${ }^{25}$ ALA - szkoła: przyjaźni, samodzielności i odpowiedzialności, http://ala.art.pl/szkola/o-szkole (dostęp: 1.02.2017).

${ }^{26}$ Bogusław Śliwerski, „Tutoring - nowomowa”, http://sliwerski-pedagog.blogspot.com/2015/01 (dostęp: 5.10.2016). 


\section{Zakończenie}

Współcześnie dostrzegamy bogactwo różnych programów edukacyjnych i wychowawczych. Ścierają się teorie wychowawcze i koncepcje widzenia człowieka. Często wychodzą one naprzeciw potrzebom, jakie niosą przemiany społeczne, kulturalne i moralne. Na gruncie pedagogiki pośród nowych tendencji w wychowaniu na uwagę zasługuje koncepcja pedagogiki dialogu ks. Janusza Tarnowskiego, otwierająca możliwości wychowania na podstawie dialogu wszędzie tam, gdzie kształcenie i wychowanie odwołuje się do wartości ogólnoludzkich, takich jak: miłość, dobro, sprawiedliwość, tolerancja i szacunek wobec godności człowieka i jego poglądów ${ }^{27}$. Współpraca oparta na dialogu wychowawcy z wychowankiem stwarza wielorakie możliwości rozwojowe. Przyczynia się do właściwego rozumienia zarówno siebie, jak i swojego otoczenia. Dialog jako spotkanie z konkretną osobą lub transcendencją (z Bogiem) może prowadzić do przemiany wewnętrznej, do zaangażowania się, oddania się jakiejś sprawie lub osobie. To spotkanie w atmosferze autentycznego dialogu nie umniejsza roli wychowawcy, który staje się autorytetem dla wychowanka. Dialog wychowawczy znajduje tu swoje zakorzenienie w Bogu i jest odpowiedzią człowieka na Jego miłość.

Pedagogika personalno-egzystencjalna ks. Janusza Tarnowskiego ma za podstawę osobę ludzką, czyli istotę rozumną i wolną: zarówno wychowanka, jak i wychowawcę, wyrażających się w relacji dialogu. Wyklucza ona wszelką przemoc fizyczną i psychiczną, co - jak mówi autor koncepcji - „nie oznacza bynajmniej wyrzeczenia się przez wychowawcę autorytetu i jakiejś formy kierownictwa. Autorytet należy zarówno do wychowawcy, jak i do wychowanka w odpowiednim zakresie"28. Sprawia to, że tak często dziś używana, a czasami nadużywana kategoria „dialog” staje się nie tylko formą rozmowy czy relacji osobowych, ale czymś więcej. Dialog jest w jakimś sensie wartością, zakładającą wzajemny szacunek partnerów dialogu, gotowość do podjęcia trudu, aby znaleźć płaszczyznę porozumienia, nawet przy występujących często trudnościach. Wydaje się nieodzowne, aby dialog znalazł się w domu rodzinnym, szkole, Kościele i społeczeństwie. Są to bowiem miejsca, w których wychowuje się młode pokolenie. Potrzeba zatem, aby osoby odpowiedzialne za wychowanie traktowały młodego człowieka podmiotowo, respektowały jego godność i niepowtarzalność osoby, umożliwiając mu wszechstronny rozwój.

Współczesna polska rzeczywistość w obszarze edukacji wymaga mądrej, cierpliwej i długofalowej pracy wychowawczej, która koncentrowałaby się

${ }_{27}$ Teresa Wilk, Edukacja, wartości i style życia reprezentowane przez wspótczesną młodzież w Polsce w odmiennych regionach gospodarczych (Kraków: Oficyna Wydawnicza „Impuls” 2003), 33; Jan Zimny, Súčasný model autority učitel'a (Rużomberok-Lublin: Wydawnictwo KUL 2006), 340.

${ }^{28}$ Waldemar Wojdecki, „Uczniowie o nauczycielach w świetle pedagogiki personalno-egzystencjalnej”. Warszawskie Studia Teologiczne 11 (1998): 427-480. 
na chrześcijańskiej wizji człowieka wolnego i odpowiedzialnego. System edukacyjny przeżywający obecnie kryzys oraz zachodzące $\mathrm{w}$ nim negatywne zjawiska są wyrazem istniejących, poważnych problemów wychowawczych. W tej sytuacji konieczny jest model wychowania wzywający do pracy nad sobą, szukania własnej tożsamości. Potrzebni są nauczyciele, którzy byliby autorytetami dla swoich wychowanków, aby wychowywali do pełnej ludzkiej dojrzałości, odpowiedzialności za siebie i innych. Urzeczywistnienie tego modelu wiąże się z potrzebą wychowania ku wartościom i potrzebą udzielania pomocy wychowankom, aby mogli oni odkryć swoje człowieczeństwo, ponieważ (jak stwierdza Nowak) istotny dla wychowanka jest przykład wychowawcy ${ }^{29}$.

Dialog wychowawczy ubogaca inne metody pedagogiczne, o ile te skupiają się na wychowanku bez eksponowania jego indywidualizmu, przejawu apersonalizmu, w którym zanika dążność do dobra wspólnego i który stanowi zagrożenie dla życia osobowego. Różne badania potwierdzają, że stosowanie metody dialogu w praktyce pedagogicznej pozwala na korzystny rozwój dziecka w procesie edukacji zwłaszcza wczesnoszkolnej. Poszukiwanie i odkrywanie prawdy o człowieku, promowanie jego godności jako osoby i pomaganie mu w rozwoju człowieczeństwa, dziś zagrożonego przez różne teorie postmodernistyczne, laicyzację życia, relatywizm moralny czy zanegowanie wszelkich wartości, jawi się jako ważne zadanie dla rodziców i wychowawców. To wspólne zadanie wychowawcze może być realizowane w rezultacie dialogu ujmowanego jako metoda kształcenia z pożytkiem dla praktyki pedagogicznej.

Streszczenie: Dialog jest podstawowym problemem ludzkiej egzystencji, a dotyczy zwłaszcza międzyludzkiej komunikacji i międzyludzkich relacji. Jako kategoria pedagogiczna zaistniał w wielu dyscyplinach naukowych, takich jak: filozofia, teologia, psychologia czy pedagogika. Na gruncie polskiej pedagogiki, a związana z filozoficznym myśleniem, ukierunkowana na osobę, pojawiła się pedagogika personalno-egzystencjalna ks. Janusza Tarnowskiego (1919-2012), znana jako pedagogika dialogu. Dialog w rozumieniu ks. Tarnowskiego to nie tylko rozmowa, ale także metoda, proces i postawa.

Wprowadzenie przez ks. J. Tarnowskiego do wychowania kategorii pedagogicznych, takich jak: autentyczność, dialog, zaangażowanie, spotkanie, zaczerpniętych z egzystencjalizmu i połączenie ich z personalizmem, pozwala na stwierdzenie na gruncie wychowania chrześcijańskiego, że zwraca się ono ku osobie ludzkiej. Kategorie te wyrażają się w procesie wychowania, który ma na celu potrójne zadanie: wychować do autentyzmu, dialogu i zaangażowania. Dialog wychowawczy, w którym jest miejsce na rozmowę, zrozumienie, porozumienie i ewentualną współpracę, stanowi propozycję uniwersalnej metody stosowanej w procesie wychowania.

Słowa kluczowe: ks. Janusz Tarnowski, pedagogika dialogu, dialog wychowawczy, wychowanie

${ }^{29}$ Nowak, Podstawy pedagogiki, 457. 


\section{Bibliografia}

ALA - szkoła: przyjaźni, samodzielności i odpowiedzialności, http://ala.art.pl/szkola/o-szkole (dostęp: 1.02.2017).

Buber, Martin. „Wychowanie”, tłum. M. Ś., Znak 16 (1968): 448-449.

Chałas, Krystyna. Wychowanie ku wartościom. Elementy teorii i praktyki, t. 1. Lublin-Kielce: Wydawnictwo Jedność, 2003.

Nowak, Marian. Podstawy pedagogiki otwartej. Lublin: Wydawnictwo KUL, 2000.

Nowak, Marian. Teorie i koncepcje wychowania. Warszawa: Wydawnictwa Akademickie i Profesjonalne, 2008.

Rutkowiak, Joanna. „O dialogu edukacyjnym. Rusztowania kategorialne”. W: Pytanie, dialog, wychowanie, red. J. Rutkowiak, 38-56. Warszawa: Wydawnictwo Naukowe PWN, 1992.

Śliwerski Bogusław. „Tutoring - nowomowa”, http://sliwerski-pedagog.blogspot.com/2015/01 (dostęp: 5.10.2016).

Śnieżyński, Marian. Sztuka dialogu, teoretyczne założenia a szkolna i akademicka rzeczywistość. Kraków: Wydawnictwo Naukowe Akademii Pedagogicznej, 2008.

Tarnowski, Janusz. „Dialog w wychowaniu”. W: Dialog w katechezie, red. ks. Stanisław Kulpaczyński. Lublin: Wydawnictwo KUL, 1998.

Tarnowski, Janusz. Jak wychowywać? Warszawa: Wydawnictwa Akademii Teologii Katolickiej, 1993.

Tarnowski, Janusz. Jak wychowywać? W ogniu pytań. Ząbki: Apostolicum, 2003.

Tarnowski, Janusz. Jak wychowywać? Chronić tylko...? Umacniać! W ogniu pytań. Ząbki: Apostolicum, 2003.

Tarnowski, Janusz. „Kto kogo wychowuje?”. Znak 32 (1980): 1153-1164.

Tarnowski, Janusz. „Podzwonne dla pedagogiki egzystencjalistów?”. W: Idee pedagogiki filozoficznej, red. Sławomir Sztobryn, Bogusław Śliwerski, 82-92. Łódź: Wydawnictwo Uniwersytetu Łódzkiego, 2003.

Tarnowski, Janusz. „Twórcze perspektywy dialogu wychowawczego”. Chrześcijanin w Świecie 5 (1977) 53: 104-110.

Wilk, Teresa. Edukacja, wartości i style życia reprezentowane przez współczesna młodzież w Polsce w odmiennych regionach gospodarczych. Kraków: Oficyna Wydawnicza „Impuls”, 2003.

Wojdecki, Waldemar. „Uczniowie o nauczycielach w świetle pedagogiki personalno-egzystencjalnej”. Warszawskie Studia Teologiczne 11 (1998): 427-480.

Zimny, Jan. Súčasný model autority učitel’a. Rużomberok-Lublin: Wydawnictwo KUL, 2006. 
